\title{
The Applying of Cognitive Strategies and Empowering Students in Research-Based Learning on Ergonomic Course
}

\author{
Syamsul Gultom ${ }^{1}$, Dewi Endriani ${ }^{2}$, Nurman Hasibuan ${ }^{3}$ \\ \{syamsulgultom@gmail.com ${ }^{1}$ \} \\ Sports Coaching Education Program State University of Medan, Indonesia ${ }^{1,2,3}$
}

\begin{abstract}
The enhancement quality of education which is in accordance with the demands of stakeholders and the development of Science and Technology currently most related to the learning process. Learning is the heart of the educational process in an educational institution. The quality of learning can be viewed from various perceptions. At the micro level, the achievement of quality learning is the professional responsibility of a lecturer, for instance through the creation of meaningful learning experiences for students and facilities / technology which available to achieve maximum learning outcomes. At the macro level, through a quality learning system, educational institutions are responsible for the formation of qualified teaching staff, namely which can contribute to intellectual development, attitude and morals of each individual student as a member of the community. This study was conduct by Sport Science Department Faculty Of Sport Science State University Of Medan. Subject of this study were all of the students who took ergonomics courses in the 2018-2019 academic year. This action research was conducting for 3 (three) cycles, namely cycles I, II, III. Before the implementation of the first cycle action, First diagnostic tests and initial observations were hold about cognitive strategy ability of students (lecture I-II). The model and format of actions that will be given in cycle I are adjusted to the initial observations of students, while the actions applied in the second cycle were determined based on the results of reflection in the first cycle. Likewise for the third cycle was determined based on the result of reflection on cycle II. In accordance with the nature of classroom action research, then procedure for conducting research for each cycle through stages (a) planning, (b) implementing actions, (c) observation and evaluation, and (d) reflection. The application of learning models that apply cognitive strategies and empower students in research-based learning, not only can increase student independence, but students better understand and explore various concepts and principles of ergonomics through research and real practice in the field. Students can test the truth of a theory and produce new theories with various modifications to the approaches and methods of body movements, see the effect of changes in angle of movement and its benefits in achieving adjusting tools, the way and work environment to the ability of ability and limitation of the workforce so as to create working conditions that are healthy, safe, safe, comfortable and efficient. Alignment between theoretical understandings through research and successful practice in the field, this is the core of competency achievement in ergonomics courses.
\end{abstract}

Keywords: Cognitive Strategy, Research-Based Learning, Ergonomics 


\section{Introduction}

Improving the quality of education which is in accordance with the demands of stakeholders and the development of Science and Technology currently is most related to the learning process. Learning is the heart of the educational process in an educational institution. The quality of learning can be viewed from various perceptions. At the micro level, the achievement of quality learning is the professional responsibility of a lecturer, for instance through the creation of meaningful learning experiences for students and facilities / technology which available to achieve maximum learning outcomes. At the macro level, through a quality learning system, educational institutions are responsible for the formation of qualified teaching staff, namely which can contribute to intellectual development, attitude and morals of each individual student as a member of the community.

Ergonomics which is a multi and interdisciplinary approach which seeks to adapt the tools, methods and work environment towards skill ability and labor restrictions so that a healthy, safe, comfortable and efficient working condition is created (Grandjean, 1993). Indeed health and work safety is not everything, but we did not realize that without health and safety, everything has no meaning.

A thing that cannot be denied anymore that the subjects require mastery of concepts and practices, tend to be less favored by students, no exception to ergonomics courses. This is indicated by the level of competency of students in the last 3 years in the Very Good category of $0 \%$, who get the Good category by $6 \%$, Poor category by $84 \%$ and Less Category by $9 \%$. Based on the observations of researchers during the care of ergonomics courses, both when giving lectures and when correcting student assignments and exams, it turns out that students experience difficulties in the process of proving ergonomic concepts and principles. Students do not have the certainty of the truth of the theory which transferred by the lecturer during the learning process, to practice in achieving various competencies specified in the contract. It is also affects the lack of student activity in the learning process. Students sometimes only understand the theory without knowing the truth of the theory scientifically, especially the truth of the theory in practice in the field.

Therefore, the application of a strategy that can stimulate activity, thinking skills and laboratory practices with the carrying capacity of sports technology in ergonomics courses is very necessary. One of the strategies which might be applied is a cognitive strategy by empowering students in research based learning activities. This is in line with Cooney's (1979) statement that teach students for cognitive strategies in understanding theory and empower students in the mini research truth theory allows students to become more analytical in making decisions.

Research Based Learning is one of the steps to achieving effective learning (Chamdani, 2015: 669). In this learning model, students are encouraged to conduct research activities. This model can train students to think critically and carry out research activities, such as do a search, stringing hypotheses, collecting data, process data, and draw conclusions. Trisnasih (2013) concluded that "Research-based learning provides student opportunities to develop contextual concepts that emphasize real conditions with the stages that must be passed by finding new things from the research process." Jenkin et al, explain the advantages of the Research Based Learning model is provide opportunities for students to not only know the content of teaching materials, but they also have the opportunity to practice doing searches, assemble hypotheses, collect and process data, and draw conclusions, in the end it can help them get better understanding and knowledge (Yahya, 2010: 1). 
Cognitive strategy or regulation of cognitive activities according to Winkel (1996: 102) is the way someone handles their own cognitive activities especially in learning and thinking. Further explained that people who are able to regulate and direct their cognitive activities are much more efficient and effective in using all concepts and rules that have been studied, compared to those who do not have them.

Anderson \& Krathwohl (2001) stated that three kinds of cognitive strategies that are very important to be taught to students are (a) rehearsal strategies, (b) elaboration strategies and (c) organizational strategies. Rehearsal strategy is a way to memorize learning material into memory by repeating the material.

The RBL approach in this lecture is translated as learning methods involving students through a series of activities that are observative, investigative, analytical, interactive, and communicative (Garvin, 1998).

\section{Research Method}

This research was conducting for 3 (three) cycles, namely cycle I, II, and III. Before the implementation of the first cycle action, diagnostic tests are first carried out and preliminary observations about students' cognitive strategy abilities (lecture I-II). Model and format of actions to be given in cycle I were adjusted to the first observations of students, while the actions applied in cycle II were determined based on the results of reflection in cycle I. Likewise the action for cycle III is determined based on the results of reflection on cycle II.

In accordance with the nature of classroom action research, then the procedure for conducting research for each cycle through the stages of (a) planning, (b) implementing actions, (c) observation and evaluation and (d) reflection.

\section{Result Of The Research}

The application of the RBL model with cognitive strategy training, can improve student learning outcomes from cycle 1 to cycle 3 with the percentage of the number of students who had a moderate level of mastery were $72.6 \%$; $80.6 \% ; 84.7 \%$ of 35 students who took the test. Student responses to learning components and activities are positive. The level of ability of the lecturer to manage learning of the 1,2 cycles was not good with the average value of the ability category is $2.60 ; 2.72$, in cycle 3 it was included in a good category with an average ability score of 3.37 .

To improve the effectiveness and effectiveness of the RBL Model in the implementation of ergonomics learning in class, the ability of students to collaborate was not only used as an accompaniment to this model but included in the direct impact of instructional. It was means that the ability of students to collaborate must be used as one of the determinants of success in achieving learning objectives. The learning process will not run effectively if students are unable to collaborate with their friends in solving problems, reconstructing knowledge, and cooperating with each other to complete tasks.

Student awareness of their role in discussion activities, ask / dialogue, submit ideas freely and openly, cooperate in completing research assignments, very decisive for the implementation and effectiveness of the learning model developed. So it is necessary to 
develop portfolio assessments, assess performance, extended type response test to measure student growth and performance during the implementation of learning.

Research-based learning strategy and cognitive strategy training is quite effective change the habits of lecturers to dominate class activities, and the habit of students receiving passive knowledge from lecturers, and reduce student dependence on lecturers in completing learning tasks. Application of the RBL Model in the implementation of classroom learning can stimulate the experience of students in solving the problems. Students can build their own way in solving problems using logic and social experience. Likewise the research problems presented can stimulate the desire of lecturers to collaborate with lecturers in other subjects in the implementation of learning tasks.

\section{Conclusion}

Based on the result of the research it can be concluded that:

1. The achievement of the effectiveness of the RBL Model is concluded based on: (i) the percentage of many students who have a moderate level of mastery was $84.7 \%$ of the 35 students who took the test. This percentage showed that the achievement of classical student learning completeness, (ii) percentage of ideal time for each student activity category and the lecturer has been fulfilled, (iii) the average value of the category of lecturers' ability to manage learning is 3.37, including a good category, (iv) student responses to learning components and activities were positive.

2. Produced Research Based Learning Models with cognitive strategy training with the syntax of the model were ; (1) student orientation on problems, (2) organizing student learning based on research problems, (3) presentation and developing work, (4) concept findings and new strengthening of schemata, (5) analyze and evaluate the results of research problem solving.

\section{Suggestion}

Based on the conclusion of the study above, researchers give advice and recommendations to interested practitioners to implement the RBL Model in the implementation of classroom learning and researchers who want to follow up on this research. Following are the suggestions and recommendations.

1. The learning model that was produced only arrived at the development stage has not been implemented widely in other courses. To find out the effectiveness of the RBL Model in various other appropriate subject matter, recommended to lecturers and researchers to implement this model in a wider scope in other subjects. So that the results of research related to this model can be used as a reference for developing ergonomics learning models.

2. For lecturers who want to apply the RBL Model in another subject in appropriate courses can design / develop their own learning tools that are needed by paying attention to the components of the learning model and characteristics of the study material learned.

3. Lecturers who seek to improve mastery of concepts and student ability to solve problems, and increasing the interest of students studying ergonomics courses, the application of the RBL Model can be used as an alternative answer to the problem. 


\section{References}

[1] Anderson, O.W., Krathwohl, D.R.: A Taxonomy For Learning, Teaching, and Assessing (A Revision of Bloom's Taxonomy of Educational Objectives) (2001)

[2] Chamdani, M., Suryandari, K.C., Suyanto, I.: Pengembangan Model Research Based Learning dengan Pendekatan Scientific melalui Lesson Study dalam Pembelajaran IPS di Sekolah Dasar (2015)

[3] Garvin, D.A.: Building a learning organization. In "Harvard Business Review on Knowledge Management (1998)

[4] Grandjean, E.: Fitting the task to the Man..” A Texbook of Occupational Ergonomics (1993)

[5] Trisnasih, A.B.: Peningkatan Keterampilan Proses dan Hasil Belajar IPA melalui Model Research Based Learning Siswa Kelas V SD (2013)

[6] Winkel, W.S.: Psikologi Pengajaran (1996)

[7] Yahya, I.: Manajemen Empat Langkah dalam Pengembangan Bahan Ajar Berbasis Riset: Sebuah Pengalaman dari Perkuliahan Akustik di Jurusan Fisika FMIPA UNS (2010) 